\title{
Brand Naming Issues of Tourism in a Coal Mining Cluster
}

\author{
Olga Valko ${ }^{1}$, Nadezda Rabkina ${ }^{1}$, and Anna Novoklinova ${ }^{1, *}$ \\ ${ }^{1}$ Kemerovo State University, 650000, 6 Krasnaya St., Kemerovo, Russia
}

\begin{abstract}
This paper aims at providing a synthetic (semantic, social, cultural, historic) survey on the names used for the tourist and catering business entities in Kuzbass, with an attempt to discover the reason for naming trends in the region. Naming is one of the most ubiquitous and important activities in business sphere, pursuing a number of goals: (1) identifying and promoting the brand / image of a business entity; (2) making sure the business will function well because its name is alluring for clients, or the name is targeted efficiently; (3) the name renders the values and ideology of the company. Linguistically, the main ways to produce business or brand names are the following: abbreviations, shortenings and/or blends, associations, allusions / associations, rhyming, transonimization (using proper names of real or imaginary people for business names), using foreign words, significant numbers, quotations / allusions / alliterations / mythological elements. "Traditional" naming may exploit ancient elements (old-fashioned and outdated words, spelling, grammar, etc.). Naming in Kuzbass in tourist sphere does not rely heavily on mining concept, but rather exploits its regional exotics and a competitive differentiator. Recreational tourism in its naming promotes the concept of vast taiga spaces and pristine Siberian nature.
\end{abstract}

\section{Introduction}

Kemerovo Region-Kuzbass is a classic example of the resource curse of modern civilization. On the one hand, it is the largest coal mining region in Russia with one of the largest coal basins in the world. On the other hand, its pristine nature offers a huge recreational potential. The first image of "the mining heart of Russia" is more or less familiar to all Russians, while the image of Kuzbass as "the Russian Switzerland" requires a thoroughly planned official policy to give it a chance over the industrial face of the region, given the negative associations with bad ecology, moon landscapes, and miners' strikes.

Indeed, the Strategy of Social and Economic Development of Kuzbass through to 2035 mentions both directions, i.e. industrial and recreational [1]. The Strategy of Tourism Development in Kemerovo Region through to 2025 [2] also covers both industrial and recreational tourism. Winter tourism has recently received state support at the top level: in his annual state-of-the-nation address, President Putin included Sheregesh ski-resort into

\footnotetext{
*Corresponding author: r961nav@yandex.ru
} 
the national project on tourism development together with such famous touristic clusters as Altai, Sevastopol, and the Baltic coast [3].

The region faces a serious dilemma: it has to find its way between the two attraction points - industry and recreational tourism. While former mining towns all over the world are choosing the path of post-industrial tourism, Kuzbass as an actively developing mining region faces another problem: it has to develop its winter sport and recreation clusters while going on with its rapid industrial expansion. Therefore, Kuzbass has a major task of creating a two-faced image, in which the faces contradict each other, for coal mining is bound to have a negative effect on the environment and is at odds with recreational and sport tourism.

In Kuzbass, recreational tourism is represented by the abovementioned ski-resort Sheregesh, which is located in the mountainous region of Gornaya Shoriya. Unfortunately, an international Internet user might see this area as a place where mining industry destroys the traditional way of life of the indigenous peoples and pollutes the nature [4].

The naming process is an important part of regional branding. They both often reflect the economic needs and aspirations of the region. The public image of Kuzbass seems to meander between the two extremes - Kuzbass as Russia's mining center vs. Kuzbass as an alternative to expensive European ski resorts.

Meanwhile, the municipal authorities published a plan of a park dedicated to the $300^{\text {th }}$ anniversary of the region that unites industrial and ecological tourism as it involves the right bank of the Tom river with its authentic pine tree forest and historical mining monuments of the open-air museum Krasnaya Gorka. The project includes a coal museum called 'Carbonarium' headquartered in the historical building of the Kemerovo mine; a cable road that will join the factory on the left bank with the mining area on the right bank the way it was one hundred years ago; a huge monument to St. Barbara, the patron saint of coal mining and blast works; the architectural heritage of the Autonomous Industrial Colony and the Kopikuz Company as part of the Krasnaya Gorka premises; paths, view spots, cafes, etc. The main idea of the complex is to engage the notorious right bank into civilized tourism and promote the existing industrial heritage. If the developers manage to maintain the balance between industry and ecology, the park will become the embodiment of the main pathos of Kuzbass as a coal mining region with a great touristic potential [5].

Linguists and marketing experts highlight the importance of the naming process and its results in achieving a number of goals, such as (1) forming and promoting the brand of a business entity and a region at large, or even its/their total rebranding; (2) providing the grounds for successful business and economic activity; (3) carrying out indirect communication with the clients / consumers [6]. They believe that efficient naming enables and stimulates business activity.

\section{Materials and Methods}

Naming is a complex phenomenon. For example, there are several approaches to naming: (1) internal naming, (2) creative naming, (3) investigative naming. Internal naming is the result of nominating activity by the business owners, thus it is believed the cheapest and least professional process. Creative naming is a result of nominating attempts by professionals depending on their comprehensive vision of the (business) entity and their expertise and competence. Investigative naming is the result of nominating that has been tested in focus-groups or potential audience. Though, some researchers also mention one more way to nominate the business which does not belong to any of the above mentioned, i.e. call for the best name contest. In this way, clients will take up the role of nominators. These ways represent the process as either natural and spontaneous, or controlled and determined by the market. Anyway, it is quite appropriate to discuss the linguistic 
landscapes of the place [7], the symbolic structure of the place [8], and communication between the place and the media [9].

Whatever the naming type, its results are of paramount importance as they reflect the first information on the goods or services the clients are exposed to. The naming results form the initial impression of the goods or services and contribute to the consumers' perception and eventually behavior. Taking into account all mentioned above, the naming result should contain semantically laden name, code the distinctive and individualizing features, be rememberable and identifiable compared to their competitors' names.

Linguistically, the main ways to produce business or brand names are the following: abbreviations, shortenings and/or blends, associations, allusions / associations, rhyming, transonimization (using proper names of real or imaginary people for business names), using foreign words, significant numbers, quotations / allusions / alliterations / mythological elements. "Traditional" naming may exploit historical elements (oldfashioned and outdated words, spelling, grammar, etc.). Special methods of naming include the combination any of the indicated ones or exploiting the language play. Language play and puns are based on manipulating the forms and functions of linguistic elements resultant in mutual enjoyment of language users. Naming and brand development possess high culture- and lingua-creative potential that may express values and identities of their owners.

The material of the research contains linguistic elements (names of hotels, restaurants, bars, souvenirs) retrieved from the sphere of hotel and catering business and tourist souvenirs production. These are the first objects and things the tourist is exposed to, so they provide the first information about the region and its environment. Like brand names, souvenirs also have properties that distinguish the region and its constituents, identify and characterize it. The analysis was focused on the semantic interpretation of the names given to the regional hotels, restaurants, souvenirs, and slogans. Slogans became part of research as they represent a key phrase of an advertising campaign which stands completely or partly for the so-called business philosophy of the entity. Naming in tourism requires a careful balance between the clients' expectations and the company's offer, as well as regional exotics.

The objective of the analysis was to find out to what extent the names and slogans appeal to natural and industrial constituents, thus positioning themselves as part of recreational tourism or industrial tourism systems. Semantic analysis and interpretation, comparison and classification of linguistic means were the main research methods.

\section{Results and Discussion}

The Kuzbass Administration and The Kuzbass Chamber of Commerce and Industry have been holding the contest "The brand of Kuzbass" since 2010. Throughout this period, the organizers highlighted their objective to assist the participants in their search for more efficient communication and interaction with their customers, as well as self-identification and analysis of their competitive differentiators.

Remarkably enough, the organizers claimed that the history of the contest makes it possible to observe the development of the regional business sphere, pointing out the upsurge of the tourist sector in the recent decades. The digital economy will only contribute to the increase in significance of business naming and brand promotion, which eventually requires a creative approach to communicative techniques and programs.

All-Russian contest "Turisticheskiy souvenir" ("Tourist souvenir") was initiated in 2015 and has been held annually since. Kuzbass participated in it twice, in 2019 and 2020. In 2019, Kuzbass companies took no prizes in contest nominations and occupied bottom positions in the regional rating after its counterparts from Siberian Federal District. In 2020, the contest scale was impressive: 65 regions submitted 3,686 items; the finals brought 
together 34 regions with 420 items [10]. The contest nominations were numerous and versatile: an ethnographic souvenir; a city souvenir; a region souvenir; a gastronomic souvenir (beverage); a gastronomic souvenir (food); an event souvenir; a tourist rout souvenir; a museum souvenir; a toy souvenir; a souvenir idea; a souvenir line. Participants were assessed by the number of items in official nominations from the region in the national finals. The final rating embraces 27 regions, the fourth position belonging to Kemerovo oblast. The items and their linguistic components are described below.

\subsection{Souvenirs}

Empirical material demonstrates attempts of souvenir creators and nominators from Kuzbass to refer to the following areas and phenomena:

- the nature of the region (the souvenir line 'New Mezhdurechensk', etc.),

- the resources of the region (the birch bark basket 'Mariinsk berries', spice cake 'Siberian freshness', etc.),

- the history and mythology of the region (the panel picture 'Petroglyphs', the decorative plaquette 'Golden Shoria', etc.).

Nominating process exposes the prevalence of the serious mode over the humorous one. Anyway, humorous approach can be found in the following example: 'Йетина мать' (Yeti's mother); the humorous effect is achieved via the language play engaging the reference to regional officially recognized symbolic character Yeti and the Russian swear expressions with the element 'mother' (cf. Кузькина мать, Kuzma's mother, or Kuzka's mother, made famous by Nikita Khrushchev during the shoe-banging incident in the USA).

Other nominating models are based on conceptual mapping that strives to reflect Russian specifics or the regional exotics and produce emotional impact on the audience (by means of emotive components, mythological elements or symbols, etc.):

- patriotic feelings ('I'm Siberian” brand, spice cake set 'Moy Kuzbass' / 'My Kuzbass'),

- nostalgic feelings (magnets featuring the carved window casing molding from Mariinsk 'Mariinskiye okna' / 'Mariinsk windows'),

- romantic and fanciful feelings (honey spice cake set 'Таежные фантазии' / 'Тaiga fantasies'),

- tender emotions (animal brooches made of fur 'Zverobroshka'), and others.

It's important to mention the attempts of internationalization (using foreign linguistic or cultural elements). One of the attempts concerns the ski-resort Sheregesh; in many souvenirs its name is shortened to the last syllable, making it sound more English-like and introduced into phrases like 'Oh my Gesh!' (cf. Oh my God!), 'Gesh forever!', 'Gesh one love!', 'It's Gesh time!', 'Live in Gesh' and others. Shortening of the original name is also used for Promyshlennovsky District, the result 'Pro' used in souvenirs has international and positive sound (the analogous English word has positive associations: advantage, support, professionalism, etc.).

The nominators realize other linguistic and cognitive models. They set up geographical and special coordinates in their souvenir texts according to the principle of the nesting dolls stacked one into another 'Russia - Siberia - Kuzbass - Prokopyevsky') and clearly identify their location, status and interrelations. Besides, they try to make use of the linguistic potential of the proper names themselves: the city of Mezhdurechensk has a transparent meaning 'the place between two rivers', which allowed the nominators to use this idea in interpretive texts based on the scheme "between A and B", where A and B can be contrastive elements, but at the same time establish not only dichotomies but also dualities: 'mezhdu taygoy i gorodom' (between taiga and town), 'mezhdu rekordami i budushchim' (between records and future), 'mezhdu rekordami i budnyami' (between records and everyday life), 'mezhdu rekordami i slavoy' (between records and glory), 'mezhdu rabotoy 
i otdykhom' (between work and rest), 'mezhdu nebom i zemley' (between heaven and earth) and others.Being divided and united simultaneously, these slogans promise an unlimited variety of options for clients / customers.

\subsection{Hotels}

Thematically, names of Sheregesh hotels can be divided into the following groups:

1. Names related to the local chronotope, associated with the mountainous terrain and snowy winters:

- Mountain-related names: 'Vysota' ('Hill'), 'Vysota 609' ('Hill 609'), 'Gornyj' ('Mountainous'), 'Vertikal', ('Vertical'), 'Gornyj majak' ('Mountain lighthouse'), 'Jekspedicija' ('Expedition'), 'Gorki Gesh' ('Hills Gesh'), 'Lavina' ('Avalanche'), 'Prijut rajdera' ('Rider's refuge'), 'Gornaja Usad'ba' ('Mountain Mansion'), 'Monblan' ('Mont Blanc'), 'Jel'brus' ('Elbrus');

- Taiga-related names: 'Taezhnyj prival' ('Taiga Camp'), 'Shishki' ('Pine Cones'), 'Lesnye doliny' ('Forest Valleys'), 'Hozjain tajgi' ('Master of the Taiga'), 'Zapovednyj les' ('Reserve Forest'), 'Dom na zaimke' ('Hunting Cabin'), 'Shipovnik' ('Rosehip'), 'Dom v kedrah' ('A House in the Cedar Pines'), 'KedrIvanych' ('Cedar Ivanovich'), 'U lesa' ('By the Forest'), 'MedOK' ('HoneyOK'), 'Brusnika' ('Red Berry'), 'Tayga House', 'Forest Club';

- Winter-related names: 'Snezhnyj' ('Snowy'), 'Snezhok' ('Snowball'), 'Snezhinka' ('Snowflake'), 'Podsnezhnik' ('Snowdrop'), 'Orion' ('Orion', the constellation of Orion is best observed in winter months), 'Metelitsa' ('Blizzard'), 'Ays Club', 'SnowSeven', 'Snegesh', 'S.N.e.G.', 'Serebro';

- Fauna-related names: 'Medvedica' ('She-bear'), 'Belaja sova' ('White Owl'), 'Volchonok' ('Wolf Cub'), 'Krechet' ('Northern Falcon'), 'Irbis' ('Snow Leopard');

- Based on toponyms associated with winter and cold: 'Laplandija' ('Lapland'), 'Jakutjanochka' ('Little Girl from Yakutia'), 'Alaska'.

2. Names based on Russian cultural stereotypes and folklore elements: 'Izba' ('Log Hut'), 'Dobrynja' ('Dobrynya', a hero of folk tales), 'Belovod'e' ('White Waters', a legendary land), 'Staraja skazka' ('Old Fairytale'), 'U Ivanycha' ('At Ivanych's'), 'Jeti Haus' ('Yeti House'), 'V Gostjah u Jeti' ('At the Yetis'), 'Slava KPSS' ('All Hail to Communist Party', an allusion to old Soviet slogans), 'Valenok' ('Felt Shoe'), 'Bukahouse' (Buks is a Boogie Man of urban legends).

3. Variations of the local toponyms:

- Shoriya-based: 'ShorHause', 'Shoriya Port', 'Shoriland';

- Sheregesh-based: 'Staryj Sheregesh' ('Old Sheregesh'), 'Gesh' ('Gesh'), 'Sheregeshevich' ('Sheregeshevich', imitation of paternal name form), 'ShaleGesh', 'Forest House Gesh', 'Loft_gesh-42', 'ResortGesh', 'Geshhouse', 'Snegesh', 'ShERegesh's Wood' ('Sherwood');

- Others (exotic and region-related): 'Kyzyl-Kotek'.

4. Names, associated with European luxury ski-resorts: 'Malen'kaja Shvejcarija' ('Little Switzerland'), 'Grjunhof' ('Grunhoff'), 'Alpika house', 'Bella Vista', 'Ski-Park-2', 'Golden Palace', 'Mora Belle Chalet', 'Lakost', 'Scandinavian Loft', 'KenWood', 'ApresSki', 'Maverick'.

5. Traditional hotel names, not linked to the location: 'Vojazh' ('Voyage'), 'Schast'e' ('Happiness'), 'Solnechnyj' ('Sunny'), 'Politeh' ('Politechnical'), 'Storony sveta' ('Cardinal Points'), 'Light HOME', 'PROFILAK'.

6. With an emphasis on the type of dwelling: 'Hizhina djadi Sashi' ('Uncle Sasha's Cabin'), 'Vitrazhi' ('Stained Glass'), 'Afrejm' ('A-frame'), 'Prijut rajdera' ('Rider's Refuge'), 'Lesnaja zaimka' ('Forest Cabin'), 'Gornaja Usad'ba' ('Mountain Mansion'), 
'Vestern' ('Western'), 'U-dacha' ('Summer Cottage'), 'Shalash' ('Tent'), 'PARKoffKA' ('Parking'), 'Barnhouse', 'Loft_gesh-42'.

7. Pun-based, with precedent or Latin components: 'Borviha' (a variation of the 'Barvikha resort' where President Yeltsyn used to be the frequent guest of), 'Gorki Gesh' (associated with the famous 'Gorki-9' residence of the President of the Russian Federation), 'Belyj dom' ('White House'), 'FreeDom', 'Rabbit Hole';Random foreign words: 'Velvet', 'Welcome', 'Yes', 'Panda house'.

There is a certain number of naming techniques that all these examples can be traced to. Association-based naming technique means that the brand name is easy to link to the product. Sheregesh is a mountain ski-resort surrounded by taiga. This method proved to be the most productive one and has given life to 42 hotel names. Etalon-based method means imitation of a successful brand, e.g. 'Lakost' as an allusion to "Lacoste". It was not prolific, taking into consideration that chain names were excluded from the list. The method based on acronyms, abbreviation (e.g. pseudo-acronym 'S.N.e.G.'), or syncopation appeared to be quite effective as there are plenty of hotel names with sher-, shor-, and -geshincorporations. Another successful technique is the one based on neologisms that are associated with the product. This technique appeared to be intertwined with the previous method as most neologisms involved the abovementioned elements, e.g. 'Snegesh'. Personal name method (transonimization) makes a person's name part of the brand or makes the product name part of an artificial personal name, and it was quite poorly represented ('U Ivanycha', 'Dobrynja', 'KedrIvanych'). Appeal method exploits emotions, and the only two examples that can relate to this method were hotel names 'Jakutjanochka' and 'Volchonok' that include diminutive suffixes. Domain method turns web-address into a brand. We found only one example where a hashtag served as a hotel name: 'Loft_gesh42'. Superiority method, based on extreme prefixes, e.g. super-, mega-, etc., was not represented at all, neither was the rhyming method. According to the rules of naming, an effective brand name should be euharmonic, easy to remember, meaningful, and evoking positive associations. Mechanisms for creating catchy hotel names are usually pun-based and combine Cyrillic and Latin spelling, thus using the potential of both languages. For instance, 'ShaleGesh' reveals the hidden similarity between the transcription of 'chalet' and the first two syllables of the resort name, while 'Sherwood' reveals the not so obvious similarity between the word 'Sheregesh' and the legendary forest in England. 'MedOK' combines honey and 'Okey'; 'FreeДом' exploits the homophonic character of English noun suffix -dom and Russian word for home; 'PARKoffKA' incorporates English postpositive in place of a similar Russian suffix, In 'U-dacha Latinization of the first letter reveals that the Russian word for 'good luck' (-udacha-) contains a word for a country cottage, etc. Others become memorable because of the allusions they trigger: 'Hozjain tajgi' is in fact the title of a Soviet-time book about adventures in the taiga; 'Hizhina djadi Sashi' associates with the Russian translation of Uncle Tom's Cabin; 'Sherwood' reminds of the adventures of Robin Hood and his merry gang; 'Rabbit Hole' is an obvious allusion to Alice in Wonderland and turns the ski resort into a magical world of infinite opportunities; 'Gorki Gesh' and 'Borviha' speak of luxury available to top government echelons only, etc. Latin spelling and blend names that contain both Cyrillic and Latin letters are just an attempt to target a younger or foreign audience. Hotel owners seem eager to exclude Sheregesh from the rest of Kuzbass with its boring mining problems and Soviet associations and place it into some abstract international chronotope of glorious winter sports and eternal fun.

It is clear that brand developers strive to avoid any connection with the industrial character of the region it is part of, the only exception being "Loft_gesh-42" which hints at the official number of the Kemerovo region. However, an analysis of names of hotels located in the capital of this industrial region showed the same lack of connection with 
mining. The most authentic group is represented by names related to local toponyms: 'Kuzbass' ('Kuzbass'), 'Tom' ('Tom') / 'Tom River Plaza' (after the name of the river), 'Na Martem'janova' (located in the street named after pilot Martemyanov, who was born in Kemerovo), 'Kosmos' (located near cinema 'Cosmos'), 'Kem.42', and 'KemHotel'.

However, the largest group includes hotel names that could be located anywhere in Russia (or somewhere else in the world): 'Izumrud' ('Emerald'), 'Graal' ('Grail'), 'Olimp' ('Olympus'), 'Maksimum' ('Maximum'), 'Diplomat' ('Diplomat'), 'Prem'er' ('Premier'), 'Piligrim' ('Pilgrim'), 'Evrazija' ('Eurasia'), 'Gvardejskaja' ('Guards'), 'Prichal' ('Jetty'), 'Majak' ('Lighthouse'), 'Avanta' ('Avanta'), 'Istorija' ('History'), 'Vremena Goda' ('Seasons'), 'Mjod' ('Honey'), 'Alye parusa' ('Scarlet Sails'), 'Ljuks' ('Luxe'), 'Ujut' ('Cosy'), 'Dobryj dom' ('Kind House'), 'Avrora' ('Aurora'), 'Moj otel' ('My Hotel'), 'RentHome', 'Vip Hotel', 'City Plaza', 'Number 1', etc. Foreign examples are rare, Latinization mostly being a sign of luxury claims (club-hotel 'Time', 'Villa Maralis', 'Crystall De Luxe', 'Luna hotel'); even rarer are attempts of linguistic creativity: 'Akva RUM' (“aqua room” vs "aquarium”), 'ATMOSFERA', '2Pillows', 'OkeyHouse', 'Romanticheskaja novostrojka' ('Romantic New District'). Still, none of the words are from the thematic net of coal mining and industry.

\subsection{Food and Catering}

As for the food and catering sector, some restaurants of Kemerovo also exploit regional number 42 by adding it to neutral names 'PORT 42', 'Grill-Bar 42', 'Chaikhana-42', etc. There is only one restaurant that seems to have monopolized the mining theme in its interior and menu: it is the famous 'Zaboi' (coal face / mine bottom). Its owners tried to sprinkle the menu with mining-related names of dishes. The relation can be visual: for instance, such dishes as "Pasta ugol'naja" (coal pasta), spaghetti under black sauce, and "Shahtnyj stvol" (mine shaft), a chocolate cheesecake, can visually be associated with coal and mining. Some coal mining food names are only randomly linked to the dishes they represent: "Bogatstvo nedr" (mineral wealth) is a seafood salad, "Doska pocheta" (awards and recognition board) is a veal dish, "Solnce shahtera" (coal miner's sun) is a thick soup served inside a hollowed loaf of bread. Such titles as "Slava trudu" (All hail to labor!), "Progress narodov" (Progress of peoples), "Dajosh' strane uglja" (Dig coal for your country!) are allusions to Soviet slogans that used to be the part of mining environment. For some dishes, the menu description verbally explains the link to coal mining. For example, "Spusk novichka" (New Miner's Descend into the Mine), which is in fact jellied maral meat that, according to the menu, helps to deal with "the first descend into the mine", which "always causes a lot of emotions: darkness, humidity, machine noise, the rattle of mining cars". "Peremychki" (astillens / abutments) are potato pancakes that "will fill in the break between the appetizer and the main course thus supporting the rugged design of a sustainable meal". "Stahanovskaja soljanka" (Stakhanov's soup) bears an allusion to the historical figure of Aleksei Stakhanov. This coal miner from Donbass extracted a record amount of coal in 1935, after which his name became a symbol of labor efficiency and produced a net of derivatives, e.g. Stakhanovets (Stakhanovite, i.e. top performer). The menu says that this peasants' soup "will give you strength for any labor feat".

As black has become the brand color of Kemerovo region, artificially blackened food products gain some popularity. Charcoal bread was developed by local students of the former Institute of Food Industry. They claim that the formulation is not connected with the mining specialization of the region, charcoal turns bread into functional food by giving it absorption properties [11]. The bread still can be purchased in local bakeries, though it is considered overprized and targeted at a very narrow audience of young people who are open to experiments. Siberian Coal Ice-cream is another mining-related brand that claims to 
be both unusual and functional [12]. Ravioli "Miner" from Novokuznetsk have become so popular that they are exported to Moscow [13]. However, Internet editions state that black products from Kuzbass are doomed to remain a local curiosity as they are overpriced, and charcoal is a less publically accepted food dye than tahini or cuttlefish ink.

The list of Sheregesh food and catering businesses reveals the same trend as the list of its hotels. Some are associated with:

- winter and cold, e.g. 'Varezhka' ('Mitten'), 'Sugrob' ('Snowdrift');

- the terrain with its local fauna and flora, e.g. 'Panorama' ('Vista'), 'Vershina' ('Summit'), 'Nebo' ('Sky’), 'Medvezhonok' ('Bear Cub’), 'Berloga' ('Bear’s Den') 'Sky Way';

- winter sports, e.g. 'Kanatka' ('Ski Lift'), 'Finish' ('Finish'), 'Fristajl' ('Freestyle'), 'Tramplin' ('Ski-ramp')

- history or folktale allusions: 'Susanin' (Ivan Susanin was a Russian national hero of the early-17th-century who guided Polish troops on a false path deep into the Russian forest), 'Terem' ('Wooden palace'), 'Jeti Sushi' ('Yeti Sushi'), 'Jurta' ('Nomads Tent');

- local toponyms, e.g. 'Shorija' ('Shoriya'), 'Beer Gesh'.

\section{Conclusion}

The semantic analysis of brands and business entities names discovered that they construct a symbolic space which represents a social, cultural and linguistic sphere of the region. This sphere does not necessarily correlate with the actual reality of the region, but it represents its basic values, interests, desirable identities, aspirations, even things / properties to show off or impress others by. Naming and brand development synthesize not only cultural and marketing aspects: there are social and psychological phenomena, as well as linguistic creativity and patriotic exertion. By choosing word(s) and name(s), a person carries out an act of subjective assessment and captures the most significant aspects of the object.

Nominating process in tourist sector of Kuzbass demonstrates a number of characteristic features: (1) recreational tourism prevails over industrial one, that is why naming is mostly based on natural and environmental concepts or makes reference to them; (2) coal mining is presented as regional exotics and a competitive differentiator, mainly promoted in urban areas and food and catering sector; (3) there is a marked trend to upgrade or internationalize the tourist sector, and one of the ways to achieve it is introducing foreign elements in business entities names; (4) a significant part of names and brands demonstrate either humorous approach or language play which can be considered as hooks or pegs for recipients' attention making them linger deciphering the message or dealing with the associations.

\section{References}

1. Kemerovo Region-Kuzbass Government, Strategy of Social and Economic Development of Kuzbass through to 2035 (AKO, Kemerovo, 2018)

2. Kemerovo Region-Kuzbass Government, The Strategy of Tourism Development in Kemerovo Region through to 2025 (AKO, Kemerovo, 2011)

3. Putin ordered to include Sheregesh and park "Altai Foothills" into national project on tourism. URL: https://tass.ru/obschestvo/11299867

4. E. Marinova, N. Rabkina, M. Ryabova, O. Valko, E3S Web Conf. 41, 04040 (2018)

5. A historical $300^{\text {th }}$ Anniversary park and a cable road to be built in Kuzbass. URL: http://kuzbass85.ru/2020/11/24/grandioznyj-istoricheskij-park-s-kanatnoj-dorogojpoyavitsya-v-kemerove-k-300-letiyu-kuzbassa/ 
6. D. Stevenson, Branding, Promotion, and the Tourist City (Routledge, New York, 2019)

7. J. Androutsopoulos, Computer-mediated communication and linguistic landscapes (Lando, Chicago, 2014)

8. E. Ben-Rafael, International Journal of Multilingualism, 3(1), 7-28 (2006)

9. D. Gorter, Annual Review of Applied Linguistics, 33, 190-212 (2013)

10. The regions are rated by the results of All-Russian 2020 contest "Tourist souvenir". URL': https://russiasuvenir.ru/news/3496/

11. People of Kuzbass are so rugged as to eat bread with coal. URL: https://sibdepo.ru/news/kuzbassovtsy-nastolko-surovy-chto-edyat-khleb-s-uglyem.html

12. Ice cream with coal produced in Kuzbass. URL: https://hardshopmarket.ru/care/izchego-sdelan-chernyi-rozhok-v-kuzbasse-poyavilos-morozhenoe-s-uglem/

13. Black ravioli “Miner” gaining popularity in Kuzbass. URL: https://sibdepo.ru/news/vkuzbasse-nabirayut-populyarnost-chyornye-pelmeni-shahtyor.html 